\title{
СУЧАСНІ ТЕХНОЛОГІЇ ТРАНСФЕКЦІї У КЛІТИННІЙ ІНЖЕНЕРІЇ
}

\author{
Фешина М.O. \\ feshyna-fbmi@111.kpi.ua \\ Галкін О.Ю., д.б.н., проф. \\ a.galkin@111.kpi.ua \\ Національний технічний університет України \\ "Київський політехнічний інститут імені Ігоря Сікорського", \\ кафедра трансляційної медичної біоінженерії \\ м. Київ, Україна
}

Реферат - Розвиток науки та промисловості позитивно вплинув на появу та вдосконалення технологій трансфекції як одного з провідних напрямків генної інженерії. На даний момент під трансфекцією розглядають різноманітні шляхи втручання у стан окремої клітини та проведення над нею специфічних маніпуляцій, щчо призведуть до зміни фенотипу вихідної клітини. У даній статті проведено огляд та аналіз основних методів трансфекцї, які основані на невірусних методах впливу на клітину. Розглядаються види трансфекиії, щчо відрізняються за строком впливу на клітину та за типом внесеної нуклеїнової кислоти. В прочесі аналізу методів трансфекиї були розглянуті фізичні методи трансфекції, методи трансфекції на основі хімічних речовин та методи трансфекції на основі часток.

Ключові слова: генна інженерія; трансфекція; ДНК; РНК; ліпосоми; наночастинки.

\section{І. ВСТУП}

Трансфекція - один з провідних напрямків методів генної інженерії. Перші 3 методів трансфекції з'явилися ще у 70x роках минулого сторіччя, і до сих пір ця галузь зазнає стрімкого розвитку. 3 плином часу з'явилися різноманітні шляхи втручання у стан окремої клітини та проведення над нею специфічних маніпуляцій, що призведуть до зміни фенотипу вихідної клітини.

\section{II. МЕТА РОБОТИ}

Дана стаття ставить на мету розглянути та проаналізувати основні методи трансфекції, які використовуються у наш час у клітинній інженерії.

\section{III. ЗАГАЛЬНА ХАРАКТЕРИСТИКА ЯВИЩА ТРАНСФЕКЦІї}

Отже, що таке трансфекція? Трансфекція це процес введення нуклеїнової кислоти у еукаріотичні клітини невірусним методом. Коли подібний процес відбувається у сторону прокаріотичної клітини, він має назву “трансформація”. Якщо перенос чужорідної ДНК відбувається за допомогою використання вірусів, то таке явище називається трансдукцією і не зовсім відповідає критеріям.
Трансфекція може проходити за участю ДНК, а може й відбуватись трансфекція РНК, яка також використовується у сучасній генній інженерії. Розглянемо види трансфекції детальніше.

\section{IV. ВИДИ ТРАНСФЕКЦЇ̈}

\section{Трансфекція ДНК - стабільна та тимчасова}

Трансфекція може використовуватись 3 різною метою, тому використовуються й різні принципи впливу на вихідну клітину. Існує дві окремі категорії, які відносяться до трансфекціїі ДНК - трансфекція стабільна (або постійна) та трансфекція тимчасова. Стабільна і тимчасова трансфекція розрізняються за своїм довгостроковим впливом на клітину; стабільно трансфікована клітина буде постійно експресувати змінену ДНК і передавати іiі дочірнім клітинам, тоді як тимчасово трансфікована клітина буде експресувати модифіковану ДНК протягом короткого періоду часу і не буде передавати іï дочірнім клітинам. Для деяких застосувань трансфекції достатньо, щоб трансфікований генетичний матеріал експресувався тільки протягом певного проміжку часу, а не постійно. Оскільки ДНК, введена в процесі трансфекції, зазвичай не інтегрується в ядерний геном, чужорідна ДНК 
розбавлятиметься за допомогою мітозу або деградує. [1]

Так, клітинні лінії, які експресують ядерний антиген 1 (EBNA1) вірусу Епштейна-Барра (EBV) або великий T-антиген SV40, дозволяють проводити епісомну ампліфікацію плазмід, що містять вірусні точки початку реплікації EBV (293E) або SV40 (293T). У результаті потрібний білок (внутрішньоклітинний r-білок) експресувався на дуже високому рівні, до 20\% від маси усіх клітинних білків, і при цьому внесена генетична інформація була тимчасовою і не зберігалась у клітині протягом довгого часу. [2]

Якщо бажано, щоб трансфікований ген дійсно залишався в геномі клітини і ії дочірніх клітин, повинна провести стабільну трансфекцію. Для цього маркерний ген спільно трансфікується, що дає клітині певні додаткові властивості, такі як стійкість до певного токсину. Деякі (далеко не всі) трансфіковані клітини випадковим чином інтегрують чужорідний генетичний матеріал в свій геном. Якщо токсин потім додається до культури клітин, тільки ті певні клітини, в геном яких інтегрований маркерний ген, зможуть проліферувати, в той час як інші клітини загинуть. Після застосування цього селективного стресу (тиску відбору) протягом деякого часу залишаються тільки клітини зі стабільною трансфекцією, i їх можна культивувати далі. Найчастіше використовуються такі речовини для відбору стабільної трансфекції як пуроміцин або генетицин, які являються токсичними як до прокаріотичних клітин, так й до еукаріотичних. [3]

\section{Трансфекція РНК - довгої та короткої}

РНК, що вводять у еукаріотичну клітину, може бути очищена після лізису або синтезована 3 нуля із вільних нуклеотидів різними засобами хімічно, або ж ферментативним шляхом із застосуванням РНК-полімерази. Молекули РНК розміром приблизно 25 нм або менше в значній мірі уникають виявлення природньою імунною системою, яка запускається, якщо у клітину потрапляє РНК більшого розміру. Більшість клітин організму експресують білки вродженої імунної системи, і при впливі екзогенних довгих молекул РНК ці білки ініціюють сигнальні каскади, які призводять до запалення. Це запалення підвищує чутливість ураженої клітини i прилеглих клітин до подальшого впливу. В результаті, хоча клітину можна багаторазово трансфікувати короткою РНК 3 невеликою кількістю неспецифічних ефектів, повторна трансфекція клітин навіть невеликою кількістю РНК великого розміру може викликати загибель клітини, якщо не буде вжито заходів для зниження дії або ухилення від вродженої імунної системи. Трансфекція короткою РНК зазвичай використовується в біологічних дослідженнях для пригнічення експресії певного білка (з використанням sіРНК) або для експресії чи блокування активності міРНК (з використанням короткої РНК, яка діє незалежно від апарату РНК клітини i, отже, не може розглядатись як siRNA). У той час як вектори на основі ДНК (віруси, плазміди), які кодують коротку молекулу РНК, також можуть використовуватися, трансфекція короткою РНК знижує ризик модифікації ДНК клітини, що призвело до розвитку використання короткої РНК як нового класу макромолекулярних препаратів. [4]

Трансфекція довгою РНК - це процес введення у еукаріотичну клітину молекул РНК, довжина яких перевищує 25 нт. Вроджена імунна система еволюціонувала для захисту від інфекції шляхом виявлення молекулярних патернів, пов'язаних 3 патогенами (РАMP), i запуску складного набору відповідей, відомих під загальною назвою “запалення”. Багато клітин експресують специфічні рецептори розпізнавання образів (РРСС) для екзогенної РНК, в тому числі Тoll-подібні рецептори 3,7,8 [5], PHК гелікази RIG1 [6], протеїнкінази R[7] та інші сполуки. Всі ці сполуки можуть викликати імунну відповідь. Як клітини відрізняють екзогенну довгу РНК від великої кількості ендогенної довгої РНК, є важливим відкритим питанням в клітинної біології і потребує подальшого дослідження. Наприклад, одні 3 досліджень показують що інгібування тільки трьох білків - інтерферону- $\beta$, STAT2 і EIF2AK2 досить того, щоб клітини людських фібробластів не загинули, що було викликано частою трансфекцією довгою РНК, що кодує білок РНК. Інгібування передачі сигналів інтерферону порушує петлю позитивного зворотного зв'язку, яка зазвичай викликає гіперчутливість клітин, які зазнали впливу екзогенною довгою РНК. [8] 


\section{V. ОСНОВНІ МЕТОДИ ТРАНСФЕКЦІЇ}

Методи, за допомогою яких можливо внесення чужорідної ДНК в клітину засновані на різних властивостях i загалом їх можна класифікувати на фізичні, або не хімічні методи, методи трансфекції на основі хімічних речовин та методи на основі частинок. До таблиці 1 винесені основні переваги методів трансфекції, що застосовуються. Розглянемо кожні 3 них детальніше.

\section{VI. МЕТОДИ НА ОСНОВІ НЕХІМІЧНИХ ЯВИЩ \\ Електропорація}

Розглянемо перший з них - електропорацію. Загалом це мікробіологічна техніка, при якій на клітини діють електричним полем, щоб збільшити проникність клітинної мембрани, дозволяючи ДНК при цьому проникати у клітину. Електропорація проводиться за допомогою електропораторів, які створюють електростатичне поле в розчині комірки. Суспензія клітин піпетується у скляну або пластикову кювету, яка має два алюмінієві електроди по боках. Електропорація найкраще працює на суспензіях клітин, при цьому успіх електропорації сильно залежить від чистоти плазмідного розчину, особливо від вмісту солі (розчини з високою концентрацією солі можуть спричинити електричний розряд, що часто знижує життєздатність бактерій), але також діє на клітинах у твердій тканині, де можна застосувати електроди. [9] При цьому ефективність передачі генів також залежить від інтенсивності імпульсів, тривалості імпульсів та частоти їх подачі. Електропорація in vivo створює перехідну проникність клітин мембрани та індукує низький рівень запалення в місці ін'єкції, сприяючи засвоєнню ДНК клітинами паренхіми та антигенпрезентаційними клітинами. Цей метод клінічно протестовано для створення вакцин на основі ДНК та для лікування онкологічних захворювань. [10, 11, 12]

Таблиця 1. Перелік переваг та недоліків основних методів трансфекції

\begin{tabular}{|c|c|c|c|}
\hline Метод & $\begin{array}{l}\text { Особливість даного } \\
\text { методу трансфекції }\end{array}$ & Переваги & Недоліки \\
\hline Катіонні полімери & Катіонний заряд & $\begin{array}{l}\text { Висока ефективність in } \\
\text { vitro, } \\
\text { легко готується }\end{array}$ & $\begin{array}{l}\text { Токсичний для клітин, низька } \\
\text { ефективність in vivo може } \\
\text { спровокувати гостру імунну } \\
\text { відповідь }\end{array}$ \\
\hline Ліпосоми & Катіонний заряд & Висока ефективність in vitro & Низька активність in vivo \\
\hline Генна пушка & Тиск & Добра ефективність & $\begin{array}{l}\text { Передача гена обмежена } \\
\text { цільовою областю, потребує } \\
\text { хірургічної процедури для } \\
\text { внутрішніх органів }\end{array}$ \\
\hline Електропорація & Електричний імпульс & Висока ефективність & $\begin{array}{l}\text { Пошкодження } \\
\text { передача генів обмежена } \\
\text { цільовою областю, потребує } \\
\text { хірургічної процедури для } \\
\text { внутрішніх органів }\end{array}$ \\
\hline Сонопорація & Ультразвук & $\begin{array}{l}\text { Висока точність доставки } \\
\text { генів }\end{array}$ & $\begin{array}{l}\text { Низька ефективність, } \\
\text { пошкодження тканин }\end{array}$ \\
\hline Магнітофекція & Магнітне поле & $\begin{array}{l}\text { Висока точність доставки } \\
\text { генів }\end{array}$ & Низька ефективність \\
\hline
\end{tabular}

\section{Cell Squeeze-метод}

Це метод, комерційна назва якого показує, що у клітину можуть потрапляти певні молекули через деформацію клітинної мембрани. Зміна тиску, порушуючи роботу клітини, досягається пропусканням клітини за допомогою вузького отвору в мікрофлюїдному пристрої. Пристрій складається 3 каналів, витравлених на пластинах, через які клітини спочатку проходять вільно, а по мірі проходження через пристрій ширина каналу поступово звужується. Гнучка мембрана клітин дозволяє їй змінювати свою форму, ставати більш тонкою і довгою, дозволяючи їй протиснутися крізь канал. У той же час це сприяє проникненню молекулмішеней у клітину крізь отвори у мембрані. [13]

\section{Сонопорація}

Сонопорація - це обробка клітин ультразвуком для досягнення зміни проникності 
плазматичної мембрани. Біоактивність цього методу аналогічна електропорації, а в деяких випадках навіть перевершує іiі. Було продемонстровано, що тривалий вплив низькочастотного $\quad(<\mathrm{MГц})$ ультразвуку призводить до повної загибелі клітин (розриву), тому при використанні цього методу також необхідно враховувати життєздатність клітин. Більш пізні дослідження на печінці мишей показали, що включення наповнених газом мікропухирців підвищує ефективність доставки генів, але порівняно 3 іншими невірусними підходами, процес передачі генів за допомогою сонопорації залишається в зародковому стані. Потрібні додаткові зусилля для підвищення його ефективності, особливо для застосувань in vivo. $[14,15]$

\section{Оптична трансфекція}

Оптичною трансфекцією називають процес введення нуклеїнових кислот в клітини використанням світла. Зазвичай лазер фокусується на дифракційно обмеженій плямі (діаметр 1 мкм) за допомогою мікроскопа 3 високою числовою апертурою. Потім плазматична мембрана клітини піддається впливу цього сильно сфокусованого світла протягом невеликого часу, при цьому на мембрані утворюється пора, крізь яку у клітину може потрапити екзогенна генетична інформація. Під час використання оптичної трансфекції обробляється одна клітина за раз, що робить іï особливо корисною для аналізу одиночних клітин. [16]

\section{Злиття протопластів}

Злиття протопластів - це техніка, при якій трансформовані бактеріальні клітини обробляють лізоцимом 3 метою видалення клітинної стінки. Після цього фузогенні агенти (наприклад, вірус Сендая, ПЕГ, електропорація) використовуються для злиття протопласта, що несе ген, що цікавить, із клітиною-реципієнтоммішенню. Основним недоліком цього методу є те, що бактеріальні компоненти також неспецифічно вводяться в клітину-мішень. Виявилось, що технологія злиття протопластів може застосовуватись разом 3 іншими специфічними технологіями - такими, як CRISPR, наприклад. Рослинні протопласти корисні для оцінки ефективності кластерних регулярно переміщених коротких паліндромних повторів (CRISPR) / пов'язаного з CRISPR білка 9 (Cas9) мутагенезу. Після трансфекції протопластів конструкціями, що кодують Cas9 та sgRNAs, цільова ДНК гена може бути ампліфікована для подальшого аналізу для визначення ефективності мутагенезу. При досліджені протопластів $N$. tabacum та похідних регенерованих рослин для цілеспрямованого мутагенезу гена фітоендесатурази (NtPDS) генотипування регенерантів альбіносів показало, що всі чотири алелі NtPDS мутували в амфідиплоїдному тютюні, і в більшості регенерованих рослин не було виявлено ДНК Cas9. [17]

\section{TРАНСФЕКЦІЯ НА ОСНОВI ХІМІЧНИХ РЕЧОВИН}

Історично склалося, що перший з методів, який застосовувався для трансфекції клітин, було використання фосфат кальцію. Буферний фізіологічний розчин-HEPES (HeBS), що містить іонні фосфати, поєднюють з розчином хлориду кальцію, що містить ДНК, яку треба помістити у клітину. Коли вони об'єднуються, утворюється тонкий осад, що містить йони позитивно зарядженого кальцію та фосфату 3 негативним зарядом, що зв'язує ДНК на своїй поверхні. Потім суспензію осадка додають до клітин (зазвичай це культура клітин, виражена в моношарі). У результаті такого процесу клітини поглинають частину осадка, а разом 3 ним і ДНК. Цей процес раніше використовувався як переважний метод виявлення багатьох онкогенів.

\section{Використання ліпосомального переносу}

Перенос генів за допомогою ліпосом був вперше описаний у 1965 році [18] і з тих пір розвивається далі. Липосома представляє собою сферичний пухирець, що має якнайменше один ліпідний біслой. У минулому було розроблено багато різних типів ліпосом, і ліпосоми, що складаються 3 катіонних ліпідів, виявляються найбільш активними в доставці генів. Ці ліпіди складаються 3 моно- або мультиплікаційних головних груп та гідрофобного якоря (аліфатичні ланцюги або холестериновий фрагмент), з'єднані між собою лінкером. Катіонні ліпосоми та ДНК стихійно взаємодіють, утворюючи комплекси (ліпоплекси) $\quad$ зі $\quad 100 \%$ ефективністю завантаження ДНК. Іншими словами, всі 
молекули ДНК укомплектовані ліпосомами за умови наявності достатньої кількості катіонних ліпосом. Ліпосомальна трансфекція має такі переваги: будучи синтетичними, вони відносно дешеві у виготовленні та не викликають хвороб, пропонують ступінь захисту ДНК від опосередкованої нуклеазою деградації, можуть переносити великі шматки ДНК, потенційно такі великі, як хромосома та може бути націлена на конкретні клітини або тканини. Крім того, ліпосоми долають проблеми, властиві вірусним векторам, пов'язані 3 імуногенністю та компетентності щодо реплікації вірусного зараження. Технології на основі ліпосом застосовуються для лікування онкологічних захворювань, зокрема меланоми. [19, 20, 21]

\section{Неліпосомні реагенти для трансфекції}

Незважаючи на те, що реагенти для ліпосомної трансфекції мають широкий спектр застосування, вони можуть бути неефективними для всіх типів клітин. Неліпосомні реагенти для трансфекції пропонують альтернативу опосередкованим ліпосомою методам трансфекції. Такі реагенти включають полімери, здатні утворювати комплекси з ДНК або РНК, та інші типи ліпідів, які можуть утворювати міцели у водних розчинах. Як і реагенти для ліпосомної трансфекції, вони пропонують низьку токсичність, відтворювані результати, високу ефективність і підходять для різних типів клітин. Катіонні полімери становлять ще одну категорію невірусних векторів, які використовувались для доставки генів. Значна кількість полімерів, таких як поліетиленімін, хітозан, полімідамін, катіонні протеїни та пептиди, вивчались як агенти для здійснення трансфекціï in vivo та in vitro. Ці катіонні полімери конденсують ДНК у дрібні частинки та запобігають деградації ДНК. Поглинання клітин відбувається через опосередкований рецепторами ендоцитоз. Подібно до катіонних ліпідів, полімери також легкі у виробництві та гнучкі для додаткових модифікацій. Насправді, поліплекси досліджуються у фазах I та II фаз клінічних випробувань для лікування муковісцидозу та очних дегенеративних захворювань. [22, 23]

\section{Реагенти на основі ліпідів}

Дані реагенти стали популярними завдяки їх простоті використання та застосовності до різних типів клітин. Наприклад, реагент для трансфекції FuGENE 6 комерційно доступний з 1997 року. 3 цього часу його популярність зросла завдяки простоті використання, мінімальному рівню цитотоксичності та високому рівню трансфекції в багатьох різних клітинних лініях. Як і у більшості реагентів, етап формування комплексу є критичним, і необхідна спеціальна обробка, оскільки реагент постачається у 80\% етанолі. Параметри, які впливають на ефективність трансфекції, включаючи використання загальних антибіотиків, рівень проходження клітин та тривалість часу для утворення комплексу часто залежать від клітинної лінії і можуть бути оптимізовані для підвищення ефективності трансфекції для конкретної клітинної лінії та культури клітин . [24]

\section{VIII. МЕТОДИ НА ОСНОВІ ЧАСТИНОК Генний пістолет}

У генній інженерії генний пістолет або біолістична система доставки частинок - це пристрій, що використовується для доставки екзогенної ДНК (трансгенів), РНК або білка до клітин. У цій методиці використовуються "мікрочастинки", які $є$ снарядами діаметром приблизно 1 мкм чи менше, які потрапляють у клітину за використанням стиснутого газу. Використання менших частинок має потенційну перевагу, дозволяючи ефективніше трансфікувати менші клітини та конкретні клітинні області. Також при використанні частинок меншого розміру стає вирішеною проблема пошкодження тканин, яка у наш час обмежує використання даної методики.

Принцип підготовки мікрочастинок для використання у біолістичній системі є таким: на поверхню “снарядів", виготовлених із золота, за допомогою специфічних агентів (наприклад, спермідину та йонів кальцію) осаджують ДНК. При створенні технології вона застосовувалась здебільшого для генетичної модифікації рослин, але у наш час сфера використання даної технології значно розширилась. Метод генного пістолету використовується для доставки генів до шкіри для вакцинації та імунної терапії через неглибоке проникнення ДНК. Цей метод був використаний при вакцинації проти вірусу грипу та в генній терапії для лікування раку яєчників. [26, 27] 


\section{Магнітофекція}

Магнітофекція використовує магнітне поле для застосування трансфекції. У магнітофекції використовуються магнітні наночастинки, виготовлені 3 оксиду заліза та покриті катіонними ліпідами або полімерами для утворення комплексу 3 ДНК за допомогою електростатичної взаємодії. Потім магнітні частинки концентруються на клітинах-мішенях під впливом зовнішнього магнітного поля. Подібно до механізму доставки гена на основі невірусного вектора, клітинне поглинання ДНК здійснюється шляхом ендоцитозу та піноцитозу. Постулюється, що ДНК виділяється в цитоплазму залежно від складу магнітних наночастинок. Магнітофекція успішно застосовується до широкого спектра первинних клітин та клітин, які важко трансфікувати за допомогою інших невірусних методів. Деякі роботи показують, що цей метод може застосовуватись не тільки in vitro, але й in vivo доставки генів. [28, 29]

\section{ІХ. ВИСНОВКИ}

Проаналізувавши основні методи трансфекції стає можливим зазначити, що загалом такий метод генної інженерії застосовується або для зміни фенотипу клітин й використання їх змінених властивостей $\mathrm{y}$ промислових потребах людини, або для спільного застосування разом 3 іншими технологіями, такими як CRISPR чи переносу вакцин безпосередньо у організм людини.

У той же час, жоден реагент для трансфекції не $\epsilon$ ідеальним для використання у всіх типах клітин та за будь-яких умов, і для будь-якого реагенту потрібна оптимізація експериментальних умов. Маючи стільки різних методів передачі генів, досить складно обрати правильний реагент або техніку трансфекції для певних клітин та при певних умовах. Відповісти на це питання стає можливим після розглядання кожного специфічного випадку. Однак для конкретного застосування можна розробити "ідеальний" спосіб доставки генів за допомогою неінвазивних шляхів доставки, здатний націлюватися на бажані клітини 3 високою ефективністю доставки та відповідною кількістю генного продукту протягом бажаного періоду часу. Враховуючи проведені на 2016 рік клінічні випробування, у $67 \%$ випадках внесення екзогенної ДНК використовувались вірусні вектори та приблизно у 24\% випадках були застосовані методи трансфекції.[30] Отже, ми можемо сказати що методи трансфекції $\epsilon$ досить перспективним шляхом для розвитку, який потерпає стрімких змін з кожним роком.

\section{Х. ПЕРЕЛІК ПОСИЛАНЬ}

[1] Kim TK, Eberwine JH (August 2010). "Mammalian cell transfection: the present and the future". Analytical and Bioanalytical Chemistry. 397 (8): 3173-8. doi:10.1007/s00216-010-3821-6. PMC 2911531

[2] Durocher Y, Perret S, Kamen A (January 2002). "High-level and highthroughput recombinant protein production by transient transfection of suspension-growing human 293-EBNA1 cells". Nucleic Acids Research. 30 (2): 9e-9. doi:10.1093/nar/30.2.e9

[3] Fanelli A (2016). "The Science of Stable Cell Line Generation". Retrieved 23 December 2017.

[4] Tansey B (11 August 2006). "Macular degeneration treatment interferes with RNA messages".

[5] Alexopoulou L, Holt AC, Medzhitov R, Flavell RA (2001). "Recognition of double-stranded RNA and activation of NF-kappaB by Toll-like receptor 3". Nature. 413 (6857): 732-738. doi:10.1038/35099560

[6] Yoneyama M, Kikuchi M, Natsukawa T, Shinobu N, Imaizumi T, et al. (2004). "The RNA helicase RIG-I has an essential function in double-stranded RNA-induced innate antiviral responses". Nat Immunol. 5 (7): 730-737. doi:10.1038/ni1087

[7] Das HK, Das A, Ghosh-Dastidar P, Ralston RO, Yaghmai B, et al. (1981). "Protein synthesis in rabbit reticulocytes. Purification and characterization of a double-stranded RNA-dependent protein synthesis inhibitor from reticulocyte lysates". J Biol Chem. 256 (12): 6491-6495

[8] Angel M, Yanik MF (2010). "Innate Immune Suppression Enables Frequent Transfection with RNA Encoding Reprogramming Proteins". PLoS ONE. 5 (7): e11756. doi:10.1371/journal.pone.0011756

[9] Saito, Tetsuichiro (2010-01-01). "Embryonic In Vivo Electroporation in the Mouse". Guide to Techniques in Mouse Development, Part B: Mouse Molecular Genetics, 2nd Edition. Methods in Enzymology. 477. pp. 37-50. doi:10.1016/S0076-6879(10)77003-8

[10] Heller LC, Ugen K, Heller R. Electroporation for targeted gene transfer. Expert Opin Drug Deliv 2005; 2: 255-68

[11] van Drunen Littel-van den Hurk S, Hannaman D. Electroporation for DNA immunization: clinical application. Expert Rev Vaccines 2010; 9: 503 17

[12] Wells DJ. Gene therapy progress and prospects: electroporation and other physical methods. Gene Ther 2004; 11: 1363-9

[13] Sharei A, Zoldan J, Adamo A, Sim WY, Cho N, Jackson E, Mao S, Schneider S, Han MJ, Lytton-Jean A, Basto PA, Jhunjhunwala S, Lee J. (February 2013). "A vector-free microfluidic platform for intracellular delivery" doi:10.1073/pnas.1218705110

[14] Bao S, Thrall BD, Gies RA, et al. In vivo transfection of melanoma cells by lithotripter shock waves. Cancer Res 1998; 58: 219-21

[15] Shen ZP, Brayman AA, Chen L, et al. Ultrasound with microbubbles enhances gene expression of plasmid DNA in the liver via intraportal delivery. Gene Ther 2008; 15: 1147-55

[16] Tsukakoshi M, Kurata S, Nomiya Y, et al. (1984). "A Novel Method of DNA Transfection by Laser Microbeam Cell Surgery". Applied Physics B: Photophysics and Laser Chemistry. 35 (3): 135-140. Bibcode:1984ApPhB..35..135T. doi:10.1007/BF00697702

[17] Choun Sea Lin, Chen Tran Hsu, Ling Hung Yang. Application of protoplast technology to CRISPR/Cas9 mutagenesis: from single cell mutation detection to mutant plant regeneration Published online 2018 Jan 10. doi: 10.1111/pbi.12870

[18] Bangham AD, Standish MM, Watkins JC. Diffusion of univalent ions across the lamellae of swollen phospholipids. J Mol Biol 1965; 13: 238-52

[19] Liu D, Ren T, Gao X. Cationic transfection lipids. Curr Med Chem 2003; 10: $1307-15$

[20] Xu L, Huang CC, Huang W, et al. Systemic tumor-targeted gene delivery by anti-transferrin receptor scFv-immunoliposomes. Mol Cancer Ther 2002; 1:337-46

[21] Stopeck AT, Hersh EM, Akporiaye ET, et al. Phase I study of direct gene transfer of an allogeneic histocompatibility antigen, HLA-B7, in patients with metastatic melanoma. J Clin Oncol 1997; 15: 341-9

[22] Sweeney P, Karashima T, Ishikura $H$, et al. Efficient therapeutic gene delivery after systemic administration of a novel polyethylenimine/DNA vector in an orthotopic bladder cancer model. Cancer Res 2003; 63: 4017-20 [23] Konstan MW, Davis PB, Wagener JS, et al. Compacted DNA nanoparticles administered to the nasal mucosa of cystic fibrosis subjects are 
safe and demonstrate partial to complete cystic fibrosis transmembrane regulator reconstitution. Hum Gene Ther 2004; 15: 1255-69

[24] Jacobsen LB, Calvin SA, Colvin KE, Wright M (June 2004). "FuGENE 6 Transfection Reagent: the gentle power". Methods. Transfection of Mammalian Cells. 33 (2): 104-12. doi:10.1016/j.ymeth.2003.11.002

[25] https://worldwide.promega.com/resources/guides/cell-

biology/transfection/

[26] Klein RM, Wolf $E D, W u$, et al. High-velocity microprojectiles for delivering nucleic acids into living cells: 1987. Biotechnology 1992; 24: 384 386
[27] Kim D, Hoory T, Monie A, et al. Enhancement of DNA vaccine potency through coadministration of CIITA DNA with DNA vaccines via gene gun. J Immunol 2008; 180: 7019-27

[28] Mykhaylyk O, Antequera YS, Vlaskou D, et al. Generation of magnetic nonviral gene transfer agents and magnetofection in vitro. Nat Protoc 2007; 2: 2391-411

[29] Jagmohan Singh, Ipsita Mohanty, and Satish Rattan In vivo magnetofection: a novel approach for targeted topical delivery of nucleic acids for rectoanal motility disorders doi: 10.1152/ajpgi.00233.2017

[30] The Journal of Gene Medicine. Gene therapy clinical trials worldwide 


\title{
СОВРЕМЕННЫЕ ТЕХНОЛОГИИ ТРАНСФЕКЦИИ В КЛЕТОЧНОЙ ИНЖЕНЕРИИ
}

Фешина М.O.

feshyna-fbmi@111.kpi.ua

Галкин А.Ю., д.б.н., проф.

a.galkin@11l.kpi.ua

Национальный технический университет Украины "Киевский политехнический институт имени Игоря Сикорского", Кафедра трансляционной медицинской биоинженерии

г. Киев, Украина

Реферат - Развитие науки и промышленности положительно повлияло на появление и совершенствование технологий трансфекции как одного из ведущих направлений генной инженерии. На данный момент под трансфекцией подразумевают различные пути вмешательства в состояние отдельной клетки и проведения над ней специфических манипуляций, которые приведут к изменению фенотипа исходной клетки. В данной статье проведен обзор и анализ основных методов трансфекиии, основанные на невирусных методах воздействия на клетку. Рассматриваются виды трансфекции, отличающиеся по сроку воздействия на клетку и по типу внесенной нуклеиновой кислоты. В процессе анализа методов трансфекции были рассмотрены физические методы трансфекции, методы трансфекции на основе химических веществ и методы трансфекции на основе частиц.

Ключевые слова: генная инженерия; трансфекция; ДНК; РНК; липосомы; наночастицы.

\section{UDC: 602.643}

\section{MODERN TRANSFECTION TECHNOLOGIES IN CELL ENGINEERING}

Feshyna M. O.

feshyna-fbmi@111.kpi.ua

Galkin A.Yu., Professor, Doctor of Biological Sciences

a.galkin@111.kpi.ua

National Technical University of Ukraine

"Igor Sikorsky Kyiv Polytechnic Institute",

Department of Translational Medical Bioengineering

Kiev, Ukra

\begin{abstract}
The development of science and industry has positively influenced the emergence and improvement of transfection technologies as one of the leading areas of genetic engineering. At the moment, transfection means various ways of interfering with the state of an individual cell and carrying out specific manipulations over it, which will lead to a change in the phenotype of the original cell. This article provides a review and analysis of the main transfection methods based on non-viral methods of influencing the cell. The types of transfection that differ in terms of the duration of exposure to the cell and the type of introduced nucleic acid are considered. In the process of analyzing transfection methods, physical transfection methods, chemical-based transfection methods and particle-based transfection methods were considered.
\end{abstract}

Key words: genetic engineering; transfection; DNA; RNA; liposomes; nanoparticles. 